\title{
UZAJAMNI UTJECAJ AKTIVNOSTI LJUDI I VIBRACIJA MEĐUKATNIH KONSTRUKCIJA
}

\author{
Ante Grubišić \\ Sveučilište J. J. Strossmayera u Osijeku, Građevinski fakultet Osijek, student \\ Ivica Guljaš \\ Sveučilište J. J. Strossmayera u Osijeku, Građevinski fakultet Osijek, prof.dr.sc.
}

\begin{abstract}
Sažetak: Međukatne konstrukcije poslovnih i stambenih zgrada mogu biti izložene djelovanju dinamičkih sila uzrokovanih ljudskom aktivnošću tijekom hoda ili povremeno zbog trčanja, skakanja ili plesa. Posljednje tri aktivnosti osobito su izražene kada poslovni objekt u svom sadržaju ima staze za trčanje, prostorije za vježbanje, plesne dvorane ili sportske dvorane, čak ako su i manjih dimenzija. Odgovarajuća dinamička opterećenja i frekventna područja nabrojanih aktivnosti su opisana u ovom članku. Vibracije međukatnih konstrukcija u stambenim i poslovnim zgradama ovise o različitim čimbenicima, kao što su tlorisni raspored pregradnih zidova, namještaja, konstrukcija stropa, koncentracije opterećenja te geometrijski oblici podova. Ovi faktori utječu ne samo na vlastite oblike i prirodne frekvencije međukatnih konstrukcija, nego i na veličinu prigušenja. Stoga, izračun dinamičkih svojstava međukatnih konstrukcija te njihova odziva poradi nabrojanih dinamičkih opterećenja može biti prilično složen, a rezultati proračuna upitni. Zato su u ovom radu prikazane empirijske i mješovite metode njihova proračuna s praktičnim rješenjima za pojedine slučajeve.
\end{abstract}

Ključne riječi: međukatne konstrukcije, vibracije, prigušenje, dinamičke sile uzrokovane ljudskom aktivnošću, hodanje, trčanje, skakanje, ples

\section{THE INTERACTION OF HUMAN ACTIVITIES AND VIBRATIONS OF FLOOR STRUCTURES}

\begin{abstract}
Floors in office or apartment buildings are subjected to the dynamic forces induced by people when they walk, and occasionally, run, jump or dance. The latter three apply especially when an office building contains facilities such as running tracks on roofs, exercise rooms, dance floors, or gymnasia, even if small in size. Relevant dynamic loadings and frequency ranges for these activities are described here. The nature of floor vibrations in office and residential buildings is influenced by many factors, among them the configuration of partitions, furnishing, ceiling structures, load concentrations and geometric shapes of floor area. These factors not only affect the mode shapes and natural frequencies of the floors, but also the damping. Rational calculations of vibration amplitudes induced by dynamic forces become rather complicated and uncertain. Consequently, empirical and semi-empirical methods have been developed to deal with this situation. Such a method is presented as a practical design tool for certain cases.
\end{abstract}

Key words: floor, vibration, mode shapes, damping, dynamic forces induced by people, walk, run, jump, dance 


\section{Uvod}

Svako gibanje koje se ponavlja u nekom vremenskom intervalu nazivamo vibracijom. Uzroci vibracija međukatnih konstrukcija mogu biti različiti. Obično se radi o vibracijama uzrokovanim ljudskom aktivnošću (hodanje, skakanje, ples, vježbanje i slično). Uzrok može biti i rad mehaničke opreme: grijanje, ventilacija, klima-uređaji, ako nisu dobro izolirani, mogu dovesti do ozbiljnih poteškoća. Nadalje, ljudska aktivnost i strojevi koji se i ne nalaze na promatranoj međukatnoj konstrukciji, mogu također uzrokovati neugodne vibracije, kao i promet te razni radovi koji se rade u blizini.

Ljudi različito doživljavaju određenu razinu vibracija, ovisno o aktivnostima kojima se u bave u tom trenutku. Tako, na primjer, osoba koja se odmara ili koja se bavi nekakvim tihim radom imat će manji stupanj tolerancije na vibracije nego osoba koja se bavi fizičkom aktivnošću kao što su ples ili vježbanje. Vibracije međukatnih konstrukcija mogu kod ljudi izazvati nelagodu i strah, iako je taj strah najčešće neopravdan zbog relativno malih progiba i time izazvanih relativno malih dodatnih naprezanja. Ipak, takve vibracije se smatraju nepoželjnima, jer utječu na opće stanje ljudi i njihovu sposobnost da normalno funkcioniraju, a time i na opću funkcionalnost objekta.

Međukatna konstrukcija složen je dinamički sustav. Ima mnogo oblika vibriranja, ali je samo u nekoliko prvih sadržan veći dio energije vibracija. Problemi s vibracijama nastaju kada je frekvencija uzbudne sile jako bliska ili se podudara s jednom od vlastitih frekvencija konstrukcija. Tada dolazi do rezonancije, što uzrokuje povećanje amplituda vibracija. Stoga različiti pravilnici daju smjernice za analizu vibracija međukatnih konstrukcija na način da definiraju donje granične vrijednosti vlastite frekvencije konstrukcije. Novi trendovi u izgradnji koji zbog pojave novih materijala naginju ka većim rasponima i lakšim konstrukcijama, čime se smanjuju krutost i vlastita frekvencija konstrukcije, rezultirali su povećanjem neugodnim osjeta vezanih uz vibracije međukatnih konstrukcija od strane korisnika objekata.

Ljudi koji hodaju, trče, skaču ili plešu, zapravo dinamički djeluju na međukatne konstrukcije u stambenim i poslovnim zgradama. Takvo ritmičko kretanje koje traje dulje od nekoliko deseteka sekundi, može rezultirati gotovo periodičkim dinamičkim silama. Takve sile mogu dovesti do manje-više ustaljenih vibracija konstrukcije. Ako se takvo ponašanje ljudi poveže s glazbenom pratnjom, kretanje postaje još sinkroniziranije, što dovodi do gotovo linearnog povećanja dinamičkih sila s brojem ljudi koji sudjeluju u spomenutim aktivnostima.

Kod dimenzioniranja međukatnih konstrukcija na dinamičko opterećenje zbog djelovanja ljudi za stanje uporabljivosti, krutost konstrukcije i rezonancija dvije su najznačajnije osobine. Kriteriji ponašanja su se prije isključivo oslanjali na ograničavanje veličine progiba od promjenjivog opterećenja, kao funkcije raspona konstrukcije te odnosa raspona i visine poprečnog presjeka konstrukcijskih elemenata [13]. Upravo šira uporaba lakih konstrukcija za premošćivanje velikih raspona skrenula je pozornost na nedostatak primjene samo takvih kriterija. Danas se ipak više pažnje posvećuje analizi dinamičkih svojstava konstrukcija, a osobito određivanju rezonantnih pojava te vršnog ubrzanja koji su u izravnoj vezi s time kako ljudi percipiraju određene vibracije. U normama i pravilnicima mogu se pronaći različite tablice, krivulje i preporuke o prihvatljivim graničnim vrijednostima navedenih parametara. U ovom radu dan je pregled nekolicine takvih smjernica, što bi uz opis osnovnih parametara nabrojanih ljudskih aktivnosti te elemenata dinamičkog ponašanja međukatnih konstrukcija, uz nekoliko primjera, trebalo skrenuti pozornost projektanata, ali i samih korisnika objekata.

\section{Reakcija ljudi na vibracije međukatnih konstrukcija}

Čovjek ima izrazito razvijen osjet na vibracije. Ljudsko tijelo može osjetiti vibracije s amplitudama pomaka od svega $0,001 \mathrm{~mm}$, dok su vršci prstiju i do 20 puta osjettjiviji [2]. U svakom slučaju, reakcija ljudi na vibracije je složena pojava i zavisi od više čimbenika. Osim amplitude vibracija, bitno je okruženje u kojemu se osoba nalazi, ali i subjektivna percepcija pojedinca. Stalno gibanje obično više uznemiruje nego vibracije uzrokovane povremenim impulsom. Razina vibracija koja se percipira kao uznemirujuća u prostorijama gdje je radna 
atmosfera, u pravilu je viša nego u prostorima koji su predviđeni za odmor. Reakcija starijh ljudi obično je značajno drugačija nego kod mlađih koji su izloženi jednakoj razini vibracija. Pokazalo se da su ljudi najosjetljiviji na vibracije frekvencija između 4 i $8 \mathrm{~Hz}$ za vibracije u smjeru osi z i na vibracije frekvencija od 0 do $2 \mathrm{~Hz} \mathrm{za}$ vibracije u smjerovima x i y osi (koordinatni sustav kao na slici 1) [14]. Dakle, parametri koji utječu na ljudsku osjetljivost na vibracije su [2]:

- položaj tijela promatrača (stajanje, sjedenje, ležanje)

- smjer vibracija u odnosu na položaj kralježnice (slika 1)

- aktivnost promatrača (odmaranje, hodanje, fizički rad)

- podjela iskustva s drugima

- dob i spol promatrača

- učestalost pojave vibracija i doba dana.
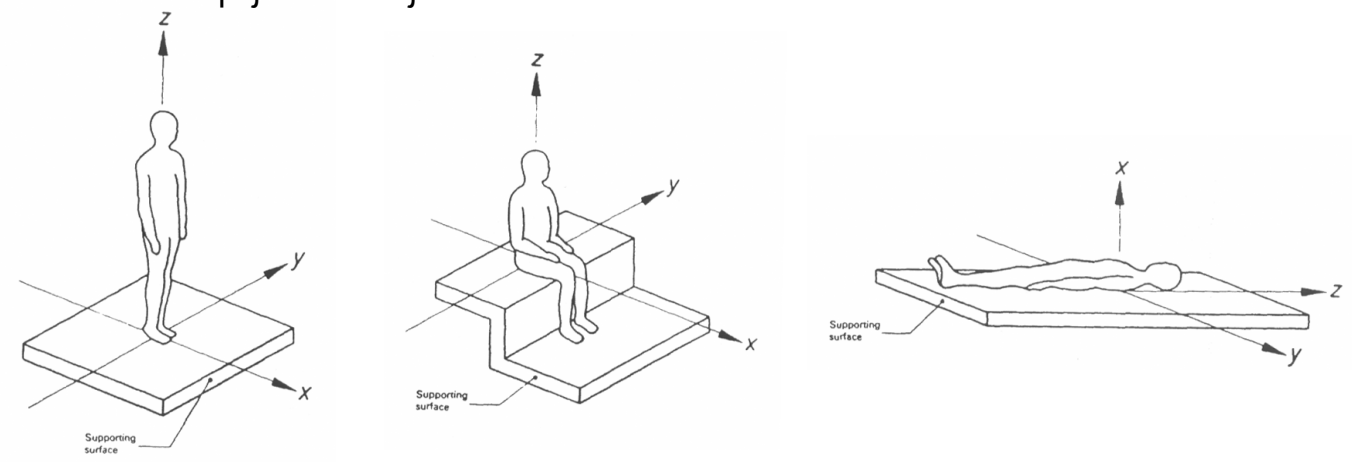

\section{Slika 1 - Referentni koordinatni sustav s obzirom na položaj ljudskog tijela [14]}

Jakost osjeta ovisi o:

- amplitudi pomaka, brzine i ubrzanja

- vremenu trajanja vibracija

- frekvenciji vibracija.

Rezultati istraživanja o promjeni osjeta povećanjem frekvencije vibracija, prikazani su u tablici 1. Općenito, u intervalu od 1 do $10 \mathrm{~Hz}$ jakost osjeta proporcionalna je akceleraciji, dok je u intervalu od 10 do $100 \mathrm{~Hz}$ proporcionalna brzini vibracija.

\section{Tablica 1 - Granice osjeta vertikalnih harmonijskih vibracija (osobe stoje)[14]}

\begin{tabular}{|c|c|c|}
\hline Opis & $\begin{array}{c}\text { Frekvencije od } 1 \mathrm{do} 10 \mathrm{~Hz} \\
\text { Vršno ubrzanje }\left[\mathrm{mm} / \mathrm{s}^{2}\right]\end{array}$ & $\begin{array}{c}\text { Frekvencije od 10 do } 100 \mathrm{~Hz} \\
\text { Vršna brzina }[\mathrm{mm} / \mathrm{s}]\end{array}$ \\
\hline Jedva osjetno & 34 & 0,5 \\
Jasno osjetno & 100 & 1,3 \\
Neugodno / uznemirujuće & 550 & 6,8 \\
Teško podnošljivo & 1800 & 13,8 \\
\hline
\end{tabular}

\section{$3 \quad$ Kriteriji za oblikovanje međukatnih konstrukcija}

Donedavno, bilo je predloženo više različitih, manje ili više uspješnih kriterija koji su trebali ograničiti vibracije međukatnih konstrukcija i učiniti prostorije ugodnima za boravak [13]. U nastavku je prikazan kriterij koji se danas najčešće koristi za oblikovanje međukatnih konstrukcija pod djelovanjem dinamičkih sila uzrokovanih hodanjem i ritmičkim aktivnostima. Kriterij i metodu za dimenzioniranje međukatnih konstrukcija na dinamičke sile uzrokovane hodanjem prvi su predložili Allen i Murray (1993). lako je predloženi kriterij složeniji nego prethodni „heel drop“ pristup (koji je također u ovome poglavlju opisan), ima široku primjenu i rezultira ekonomičnijim, ali ništa manje, s gledišta ograničenja vibracija, prihvatljivim konstrukcijama. 


\subsection{Dinamička pobuda u obliku hodanja}

\subsubsection{Metoda „Heel-drop“ (udar pete)}

Ovo je empirijska metoda koja se dugo koristila s ciljem da se izbjegnu neugodne vibracije međukatnih konstrukcija stambenih i uredskih zgrada i davala je zadovoljavajuće rezultate za konstrukcije s frekvencijama nižim od $10 \mathrm{~Hz}$ i rasponima većim od $8 \mathrm{~m}$. Metoda je posebno odgovarala za čelične međukatne konstrukcije, ali se također koristila i za spregnute i armiranobetonske međukatne konstrukcije [2]. Metoda se temelji na analizi odgovora konstrukcije na impuls nastao udarom pete o pod osobe teške $700 \mathrm{~N}$. Osoba bi stala na prste te naglo spustila pete na pod stvarajući udar koji bi izazvao vibracije konstrukcije. Ovaj postupak se koristio pri dimenzioniranju novih, ali i pri procjeni stanja postojećih međukatnih konstrukcija. Postupak proračuna čine sljedeći koraci:

1) određivanje najniže vlastite frekvencije konstrukcije;

2) određivanje vršne akceleracije pomoću izraza [2]:

$$
\begin{array}{cl}
a_{0}=\frac{2 \pi \cdot f \cdot I}{M} \cdot 0,9 & \\
\text { gdje su: } f & \text { - najniža vlastita frekvencija konstrukcije } \\
I & \text { - impuls koji predstavlja udar pete }=67 \mathrm{Ns} \\
M & \text { - masa konstrukcije }
\end{array}
$$

3) određivanje vrijednosti koeficijenta prigušenja $\xi$

\section{Tablica 2 - Preporučene vrijednosti koeficijenta prigušenja [2]}

\begin{tabular}{|l|l|}
\hline goli pod & 0,03 \\
gotov pod (pod, strop, namještaj) & 0,06 \\
gotov pod s pregradnim zidovima & 0,12 \\
\hline
\end{tabular}

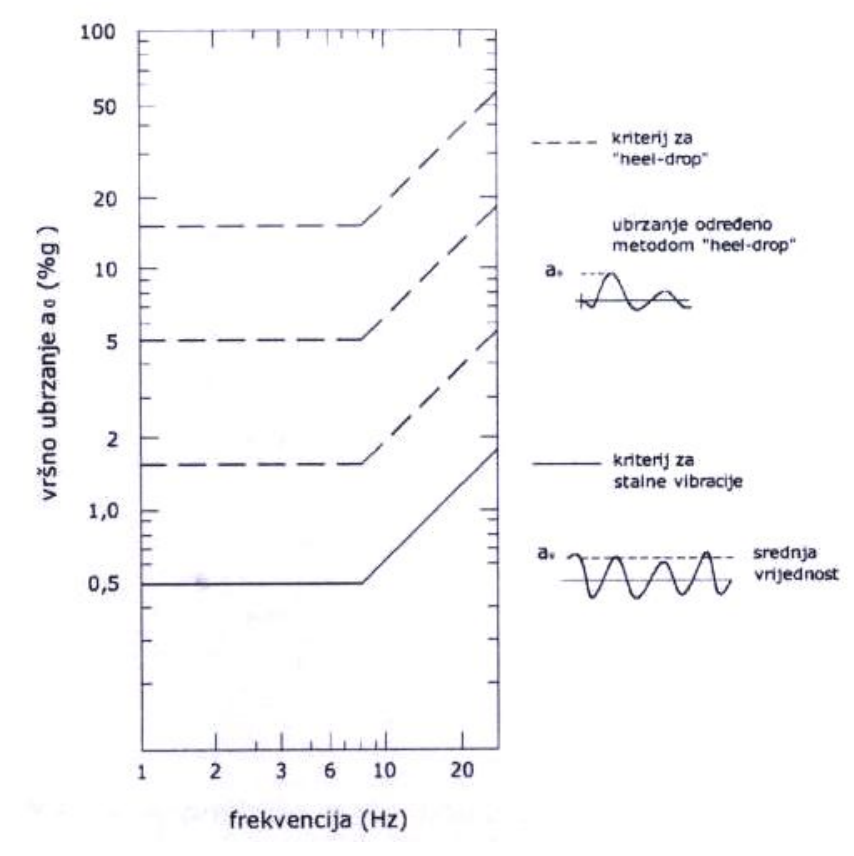

Slika 2 - Preporučene maksimalne vrijednosti vršnog ubrzanja [2] 
4) dobivena vrijednost akceleracije iz jednadžbe (1) uspoređuje se s pripadnom preporučenom maksimalnom vrijednošću pomoću krivulja sa slike 2 (primijetimo da su vrijednosti vršnog ubrzanja ovisne o prigušenju konstrukcije).

Konstrukcija zadovoljava ako je izračunata vrijednost ubrzanja konstrukcije manja od pripadne vrijednosti očitane s krivulja na slici 2.

\section{Allen-Murray-ev pristup}

Kriterij se bazira na istraživanju dinamičkog odgovora čeličnih međukatnih konstrukcija na sile hodanja, a može se koristiti za ocjenu stanja međukatnih konstrukcija u uredima, trgovačkim centrima, pješačkim mostovima i sličnim prostorima. Temelji se na sljedećim pretpostavkama:

- Vršna akceleracija međukatne konstrukcije ograničena je kako je prikazano na slici 3. To je grupa krivulja koju preporuča ISO (International Standards Organization ISO 2631-2, 1989), a koja prikazuje ovisnost maksimalne dopuštene akceleracije o vlastitoj frekvenciji konstrukcije i namjeni prostora. Donja krivulja je bazna krivulja koja se množi s koeficijentima ovisnima o namjeni budućeg prostora (10 - za urede, 30 - za trgovačke centre i unutarnje pješačke mostove, 100 - za vanjske pješačke mostove). Ove granice mogu varirati od 0,8 do 1,5 puta, ovisno o duljini trajanja i frekvenciji vibracija.

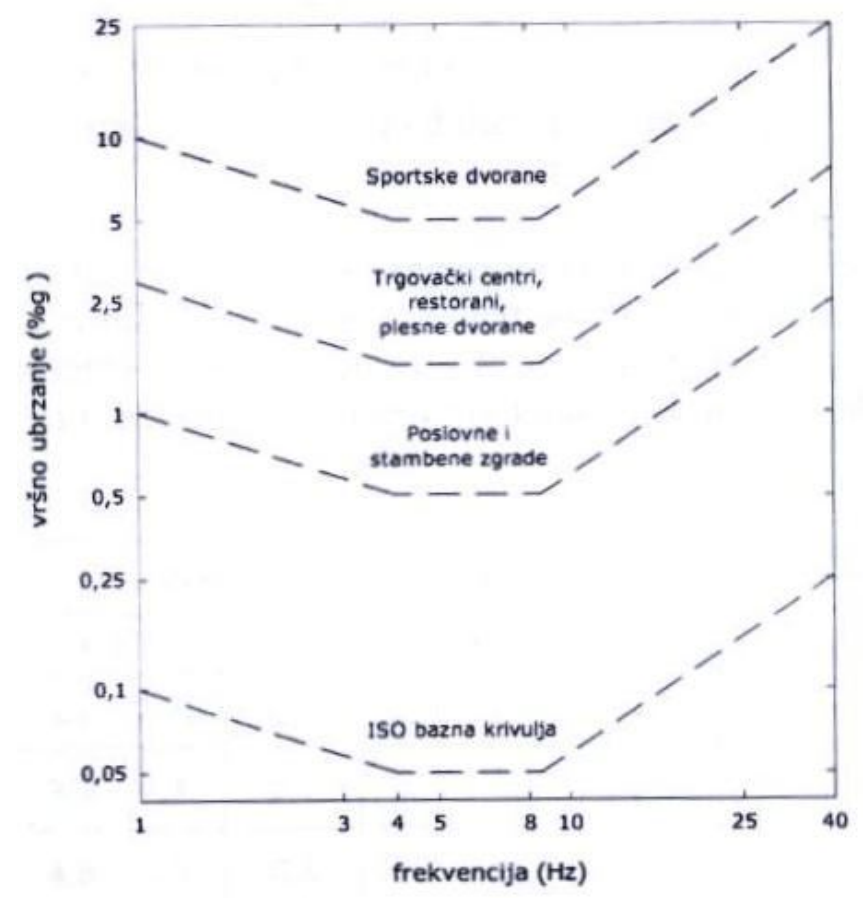

Slika 3 - Preporučene maksimalne vršne akceleracije vibracija uzrokovanih ljudskom aktivnošću [11,13]

- Vremenski promjenjiva komponenta uzbudne harmonijske sile koja se podudara s osnovnom prirodnom frekvencijom konstrukcije, dana je izrazom $[2,7,10,13]$ :

$$
F_{i}=P \alpha_{i} \cos \left(2 \pi i f_{\text {step }} t\right)
$$

gdje su: $P \quad$ - težina osobe (koja se u propisima standardizirana na $0,7 \mathrm{kN}$ )

$a_{i} \quad$ - dinamički koeficijent za $i$-ti oblik uzbudne sile

i - prirodni broj (višekratnik frekvencije uzbudne sile - "harmonic multiple")

$f_{\text {step }} \quad$ - frekvencija koraka. 
- $\quad$ Funkcija odgovora pri rezonanciji je oblika:

$$
\frac{a}{g}=\frac{R \alpha_{i} P}{\xi W} \cdot \cos \left(2 \pi i f_{\text {step }} t\right)
$$

gdje su: $a / g \quad$ - omjer akceleracije međukatne konstrukcije i gravitacijske akceleracije

$$
\begin{array}{ll}
R & \text { - faktor redukcije } \\
\xi & \text { - modalno prigušenje (prigušenje za pojedini oblik vibracija) } \\
W & \text { - efektivna težina međukatne konstrukcije. }
\end{array}
$$

Faktor redukcije $R$ uzima u obzir činjenicu da do rezonancije dolazi samo povremeno i da osoba koja hoda i promatrač nisu istovremeno na mjestu maksimalnih pomaka. Faktor redukcije $R$ je 0,7 za pješačke mostove, a 0,5 za međukatne konstrukcije koje vibriraju u obliku slova S.

Tablica 3 - Uobičajene frekvencije uzbudne sile (f) i dinamički koeficijenti (a) [13]

\begin{tabular}{|c|c|c|c|c|c|c|}
\hline \multirow{2}{*}{$\begin{array}{c}\text { Oblik } \\
i\end{array}$} & \multicolumn{2}{|c|}{ Hodanje } & \multicolumn{2}{c|}{ Aerobik } & \multicolumn{2}{c|}{ Ples } \\
\cline { 2 - 7 } & $f[\mathrm{~Hz}]$ & $a_{i}$ & $f[\mathrm{~Hz}]$ & $a_{i}$ & $f[\mathrm{~Hz}]$ & $a_{i}$ \\
\hline 1 & $1,6-2,2$ & 0,50 & $2,0-2,75$ & 1,50 & $1,5-3,0$ & 0,50 \\
\hline 2 & $3,2-4,4$ & 0,20 & $4,0-5,5$ & 0,60 & - & - \\
\hline 3 & $4,8-6,6$ & 0,10 & $6,0-8,25$ & 0,10 & - & - \\
\hline 4 & $6,4-8,8$ & 0,05 & - & - & - & - \\
\hline
\end{tabular}

Pomoću jednadžbe 3 lako se može provjeriti zadovoljava li neka postojeća konstrukcija navedene kriterije, i to na sljedeći način:

a) vršna akceleracija uzrokovana hodanjem odredi se pomoću jednadžbe 3 i to tako da se odabere najniži oblik $i$ čija je frekvencija $f=i \cdot f_{\text {step }}$ bliska vlastitoj frekvenciji međukatne konstrukcije;

b) dobivena vršna akceleracija usporedi se s pripadnom graničnom vrijednosti iz grafa na slici 3.

Za potrebe projektiranja međukatnih konstrukcija, izraz 3 može se pojednostaviti tako da se odnos između dinamičkog koeficijenta $\alpha_{i}$ i frekvencije $f$ aproksimira jednadžbom $\alpha=0,83 \cdot e^{-0,35 f_{n}}$ (slika 4). Tom zamjenom dolazimo do sljedećeg kriterija [13]:

$$
\frac{a_{p}}{g}=\frac{P_{0} \cdot 0,83 \cdot e^{-0,35 f_{n}}}{\xi W} \leq \frac{a_{0}}{g}
$$

gdje su: $a_{p} / g \quad$ - vršna akceleracija (izražena kao dio gravitacije)

$a_{n} / g$ - maksimalna dopuštena vrijednost s krivulje na slici 3

$f_{n} \quad$ - vlastita frekvencija međukatne konstrukcije

$P_{0} \quad$ - kontantna sila koja je jednaka $0,29 \mathrm{kN}$ za stropne konstrukcije i $0,41 \mathrm{kN}$ za pješačke mostove

Brojnik $P_{0} \cdot 0,83 \cdot e^{-0,35 f_{n}}$ u nejednakosti 4 predstavlja efektivnu harmonijsku silu uzrokovanu hodanjem koja izaziva rezonanciju kod stropne konstrukcije $s$ vlastitom frekvencijom $f_{n}$. 


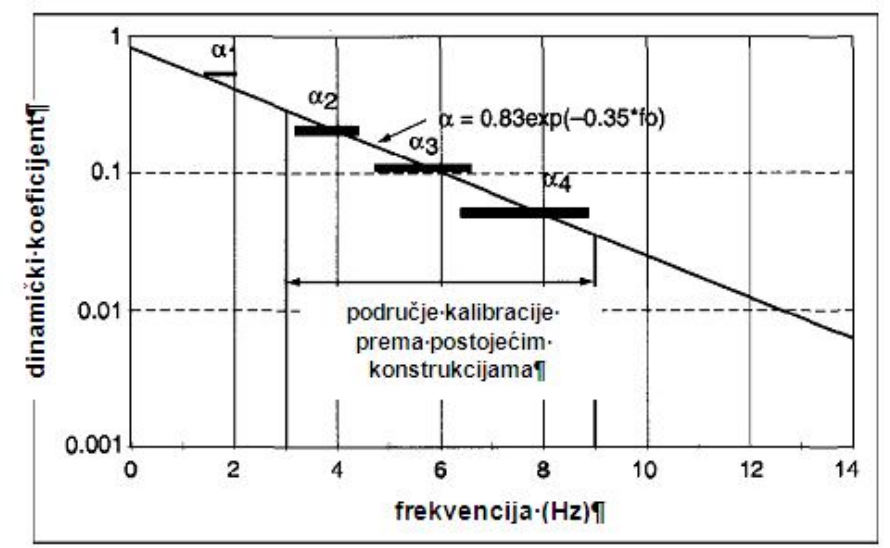

Slika 4 - Odnos između frekvencije i dinamičkog koeficijenta $\alpha_{i}[13]$

\section{Dinamička pobuda uzrokovana ritmičkim aktivnostima}

Kriteriji za oblikovanje međukatnih konstrukcija na djelovanje pobude zbog ritmičkih aktivnosti, temelje se na dinamičkom odgovoru konstrukcije na dinamičku silu jednoliko raspodijeljenu po cijeloj površini (Allen 1990). Ti kriteriji se koriste pri projektiranju međukatnih konstrukcija prostora koji su predviđeni za događanja kao što su aerobik, ples, sportske aktivnosti i slično, gdje se grupe ljudi zajedno gibaju u određenom ritmu, što rezultira velikim dinamičkim silama (slike 5 i 6 ).

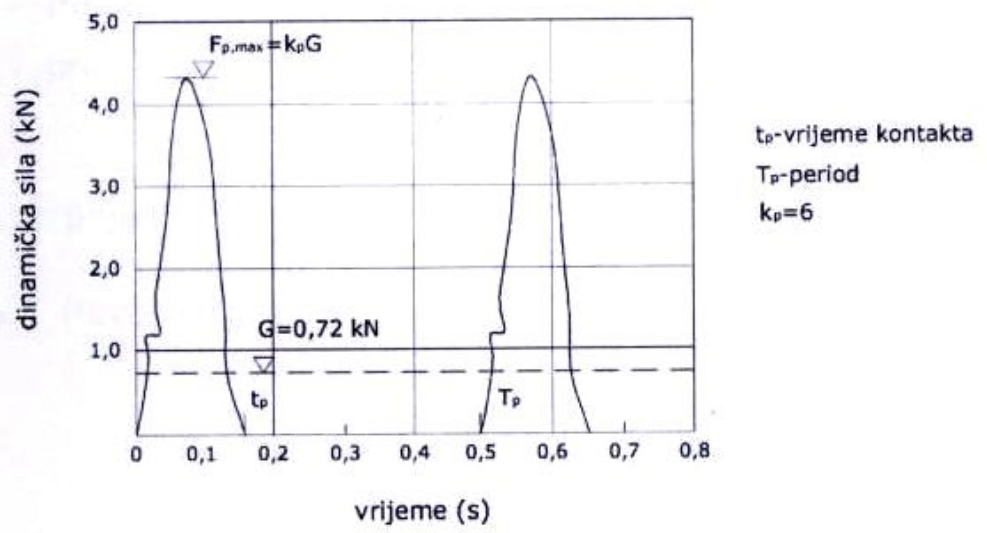

Slika 5 - Primjer funkcije dinamičke sile zbog skakanja na mjestu s obje noge istovremeno, $f=2 \mathrm{~Hz}$ [2]

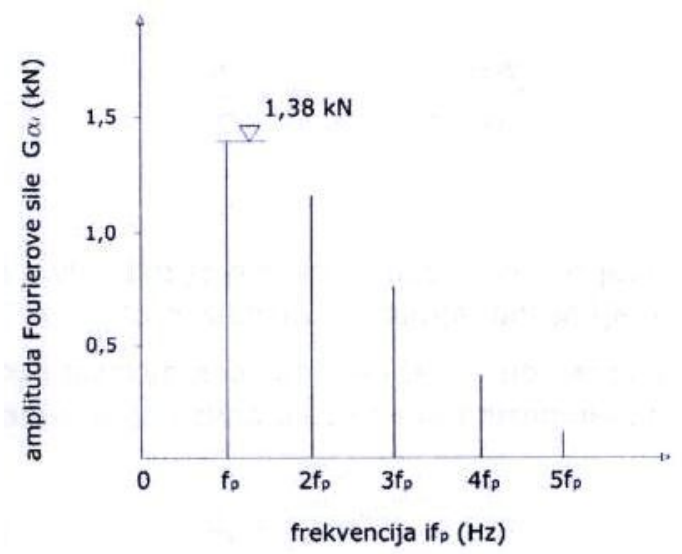

Slika 6 - Diskretni Fourierov spektar za dinamičku silu prikazanu na slici 5 [2] 
Vršna akceleracija konstrukcije zbog djelovanja harmonijske ritmičke sile može se dobiti iz jednadžbe 4, pod pretpostavkom da konstrukcija ima samo jedan oblik vibracija [13]:

$$
\frac{a_{p}}{g}=\frac{1,3 \alpha_{i}{ }^{W_{p}} / W_{t}}{\sqrt{\left(1-r^{2}\right)^{2}+(2 \xi r)^{2}}}
$$

gdje su: $a_{p} / g$ - vršna akceleracija (izražena kao dio gravitacije)

$a_{i} \quad$ - dinamički koeficijent (vidi tablicu 3)

$W_{p} \quad$ - efektivna težina ljudi (koji sudjeluju u ritmičkoj aktivnosti) po $\mathrm{m}^{2}$ površine poda

$W_{t} \quad$ - efektivna težina ljudi (koji sudjeluju u ritmičkoj aktivnosti) i stropne konstrukcije po $\mathrm{m}^{2}$ površine poda

$f_{n} \quad$ - vlastita frekvencija stropne konstrukcije

$f \quad$ - frekvencija uzbudne sile, $f=i \cdot f_{\text {step }}$

$\xi \quad$ - prigušenje.

Jednadžba 5 može se pojednostaviti [13]:

- $\quad$ kada je $f_{n}=f($ rezonancija):

$$
\frac{a_{p}}{g}=\frac{1,3}{2 \xi} \cdot \frac{\alpha_{i} W_{p}}{W_{t}}
$$

- $\quad$ kada je $f_{n}>1,2 f$ :

$$
\frac{a_{p}}{g}=\frac{1,3}{\left(f_{n} / f\right)^{2}-1} \cdot \frac{\alpha_{i} W_{p}}{W_{t}} .
$$

Većina problema se javlja ako je jedan od oblika uzbudne sile jednak ili blizak vlastitoj frekvenciji konstrukcije, $f=i \cdot f_{\text {step, }}$, te se u tom slučaju akceleracija određuje iz jednadžbe 6a. Za niže oblike, koji također mogu izazvati značajne vibracije, akceleracija se računa iz jednadžbe 6b. Efektivna maksimalna akceleracija, koja uzima u obzir sve oblike, računa se po izrazu [13]:

$$
a_{m}=\left[\sum a_{i}^{1,5}\right]^{1 / 1,5}
$$

gdje je: $a_{i}$ - vršno ubrzanje za $i$-ti oblik.

Dakle, ako se želi provjeriti zadovoljava li neka postojeća konstrukcija kriterij o ograničenju vršne akceleracije, to se može učiniti na sljedeći način:

a) vršna akceleracija uzrokovana ritmičkom aktivnošću odredi se pomoću jednadžbi 6a, 6 b i 7 kako je gore navedeno i

b) dobivena vršna akceleracija $a_{m}$ usporedi se s pripadajućom graničnom vrijednosti iz krivulje na slici 2.

Iskustvo je pokazalo da vibracije nastale zbog ritmičkih aktivnosti mogu uzrokovati neugodu i kod ljudi koji borave u susjednim prostorijama $[1,2,7,10,13]$. U tom slučaju mora se vršno ubrzanje konstrukcijskim mjerama smanjiti da bi i vibracije u susjednim prostorijama, s obzirom na njihovu namjenu, bile u granicama dopuštenih. To znači da se stropna konstrukcija mora oblikovati tako da njena vlastita frekvencija, $f_{n}$, bude veća od frekvencije najvišeg harmonijskog oblika uzbudne sile koji može uzrokovati velike vibracije pri rezonanciji. U svrhu lakšeg određivanja minimalne potrebne vlastite frekvencije konstrukcije, jednadžba $6 \mathrm{~b}$ može se pisati i u obliku:

$$
f_{n} \geq f \sqrt{1+\frac{k}{\left(a_{p} / g\right)} \cdot \frac{\alpha_{i} W_{p}}{W_{t}}}
$$

gdje su: $k \quad$ - konstanta (1,3 za ples, 1,7 za glazbeni koncert ili sportska događanja, 2,0 za aerobik)

$a_{p} / g$ - maksimalno vršno ubrzanje. 
Uobičajeno je da se za dimenzioniranje međukatnih konstrukcija na djelovanje pobude zbog ritmičkih aktivnosti koriste dva jednostavna kriterija. Prvi kriterij određuje da osnovna vlastita frekvencija konstrukcije mora biti veća od gornje granice frekvencije drugog harmonijskog oblika promatrane uzbudne sile (tablica 4) [2]. Tako npr., ako je promatrana reprezentativna aktivnost „skakanje“ (tablica 5), to znači da osnovna vlastita frekvencija mora biti veća od $2 \cdot 3,4 \mathrm{~Hz}=6,8 \mathrm{~Hz}$. Kao dopuna tome služi drugi kriterij koji uzima u obzir veliku energiju koju proizvodi veća grupa ljudi i različite vrijednosti krutosti, mase i prugušenja za različite tipove konstrukcija. Time se dolazi do sljedećih minimalnih vrijednosti osnovnih vlastitih frekvencija za različite tipove međukatnih konstrukcija:

Tablica 4 - Minimalne vrijednosti frekvencija različitih međukatnih konstrukcija [2]

\begin{tabular}{|l|c|c|}
\hline & $\begin{array}{c}\text { Sportske } \\
\text { dvorane }\end{array}$ & $\begin{array}{c}\text { Plesne } \\
\text { dvorane }\end{array}$ \\
\hline konstrukcije od armiranog betona & $\mathrm{f}_{1}>7,5 \mathrm{~Hz}$ & $\mathrm{f}_{1}>6,5 \mathrm{~Hz}$ \\
konstrukcije od prednapetog betona & $\mathrm{f}_{1}>8,0 \mathrm{~Hz}$ & $\mathrm{f}_{1}>7,0 \mathrm{~Hz}$ \\
spregnute konstrukcije & $\mathrm{f}_{1}>8,5 \mathrm{~Hz}$ & $\mathrm{f}_{1}>7,5 \mathrm{~Hz}$ \\
čelične konstrukcije & $\mathrm{f}_{1}>9,0 \mathrm{~Hz}$ & $\mathrm{f}_{1}>8,0 \mathrm{~Hz}$ \\
\hline
\end{tabular}

Tablica 5 - Reprezentativne vrste aktivnosti i njihova primjena na različite stvarne aktivnosti i vrste konstrukcija [2]

\begin{tabular}{|c|c|c|c|c|c|}
\hline \multicolumn{3}{|c|}{ Reprezentativne vrste aktivnosti } & \multicolumn{3}{c|}{ Područje primjene } \\
\hline Oznaka & Definicija & $\begin{array}{c}\text { Projektna } \\
\text { frekvencija [Hz] }\end{array}$ & Stvarna aktivnost & $\begin{array}{c}\text { Stvarna } \\
\text { frekvencija } \\
{[\mathrm{Hz}]}\end{array}$ & Vrsta konstrukcije \\
\hline hodanje & $\begin{array}{c}\text { hodanje s } \\
\text { kontinuiranim } \\
\text { kontaktom s podom }\end{array}$ & 1,6 do 2,4 & $\begin{array}{c}\text { sporo hodanje } \\
\text { normalno hodanje } \\
\text { brzo hodanje }\end{array}$ & $\begin{array}{c}\sim 1,7 \\
\sim 2,0 \\
\sim 2,3\end{array}$ & $\begin{array}{c}\text { stubišta, pješački } \\
\text { koridori, poslovne } \\
\text { zgrade }\end{array}$ \\
\hline trčanje & $\begin{array}{c}\text { trčanje s } \\
\text { diskontinuiranim } \\
\text { kontaktom s podom }\end{array}$ & 2,0 do 3,5 & $\begin{array}{c}\text { sporo trčanje } \\
\text { normalno trčanje } \\
\text { sprint }\end{array}$ & $\begin{array}{c}\sim 2,1 \\
\sim 2,5 \\
>3,0\end{array}$ & $\begin{array}{c}\text { pješački } \\
\text { koridori, } \\
\text { trkaće staze }\end{array}$ \\
\hline skakanje & $\begin{array}{c}\text { srednje do jako ritmičko } \\
\text { skakanje na mjestu, } \\
\text { istovremeno s objema } \\
\text { nogama }\end{array}$ & 1,8 do 3,4 & $\begin{array}{c}\text { aerobik } \\
\text { sportski ples }\end{array}$ & $\begin{array}{c}\sim 1,5 \text { do } 3,4 \\
\sim 1,8 \text { do } 3,5\end{array}$ & $\begin{array}{c}\text { sportske } \\
\text { dvorane }\end{array}$ \\
\hline ples & $\begin{array}{c}\text { ekvivalentno brzom } \\
\text { hodanju }\end{array}$ & 1,5 do 3,0 & klasični ples & $\sim 1,5$ do 3,0 & $\begin{array}{c}\text { plesne i koncertne } \\
\text { dvorane }\end{array}$ \\
\hline
\end{tabular}

\section{Primjeri ocjene ponašanja međukatnih konstrukcija}

U nastavku su dani primjeri procjene prihvatljivosti dinamičkih karakteristika međukatnih konstrukcija na djelovanje dinamičkih opterećenja u obliku hodanja i ritmičkog kretanja. Vlastite frekvencije i oblici odabranih konstrukcija određeni su pomoću računala (SAP2000). Odabrane su dvije međukatne konstrukcije, od kojh je jedna spregnuta (čelik - beton) a druga armiranobetonska, s tlorisnom dispozicijom, presjekom i izmjerama prikazanim na slici. 


\section{Spregnuta međukatna konstrukcija (čelik-beton)}

Betonska ploča:

$$
\begin{aligned}
& \rho=1850 \mathrm{~kg} / \mathrm{m}^{3} \\
& E=16 \mathrm{GN} / \mathrm{m}^{2} \\
& d=130 \mathrm{~mm} \\
& g_{p}=2 \mathrm{kPa}
\end{aligned}
$$

Čelična greda:

$$
\begin{aligned}
& E=200 \mathrm{GN} / \mathrm{m}^{2} \\
& I P E 330
\end{aligned}
$$

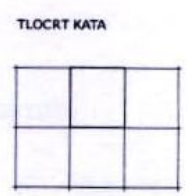

Oslonačka greda: IPE 450

\section{Armiranobetonska ploča}

Betonska ploča:

$$
\begin{aligned}
& \rho=2500 \mathrm{~kg} / \mathrm{m}^{3} \\
& E=30 \mathrm{GN} / \mathrm{m}^{2} \\
& d=20 \mathrm{~cm} \\
& g_{p}=5 \mathrm{kPa}
\end{aligned}
$$
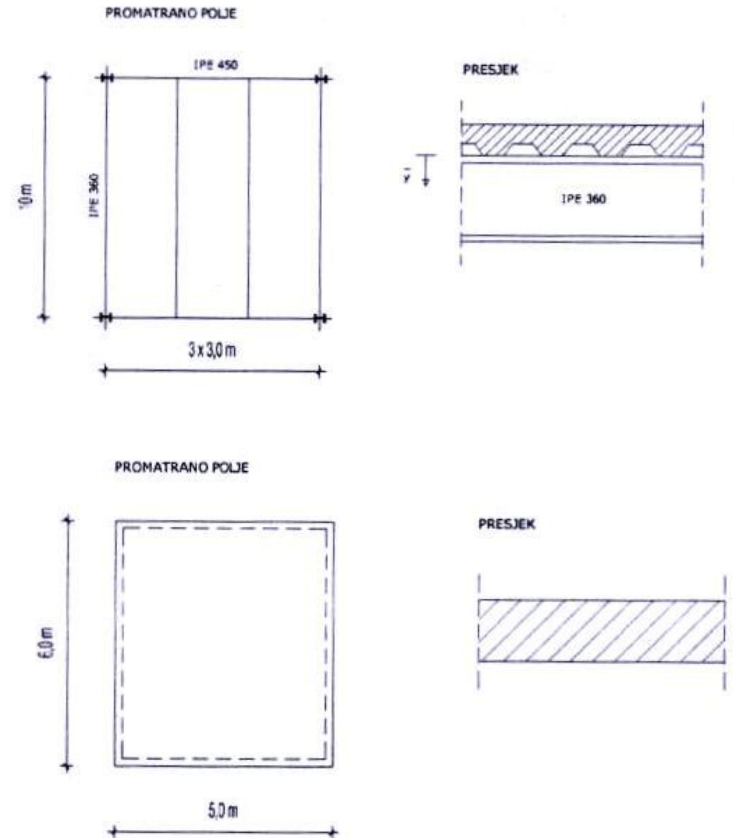

TLOCRT KATA

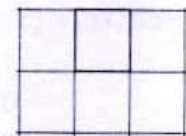

\subsection{Hodanje kao dinamičko opterećenje}

Zadaća je ocijeniti odabrane međukatne konstrukcije na temelju vibracija izazvanih hodanjem. Pretpostavimo da su obje konstrukcije u poslovnim prostorima bez izraženih pregradnih zidova. Odabrano je promjenjivo opterećenje od $0,5 \mathrm{kN} / \mathrm{m}^{2}$, dok je težina mehaničke opreme i drugih nekonstruktivnih elemenata $0,2 \mathrm{kN} / \mathrm{m}^{2}$. Ocjena se sastoji u provjeri dvaju kriterija:

- ocjena vršnog ubrzanja:

pri čemu su [13]

$$
\frac{a_{p}}{g}=\frac{P_{0} \cdot 0,83 \cdot e^{-0,35 f_{n}}}{\xi W} \leq \frac{a_{0}}{g}
$$

\begin{tabular}{|l|c|c|c|}
\hline & Konstantna sila $P_{0}$ & $\begin{array}{c}\text { Koeficijent } \\
\text { prigušenja } \xi\end{array}$ & $\begin{array}{c}\text { Granično ubrzanje } \\
\text { aolg } \cdot 100(\%)\end{array}$ \\
\hline Poslovne i stambene zgrade, crkve & $0,29 \mathrm{kN}$ & $0,02-0,05$ & $0,5 \%$ \\
\hline Trgovački centri & $0,29 \mathrm{kN}$ & 0,02 & $1,5 \%$ \\
\hline
\end{tabular}

- usporedba vlastitih frekvencija s preporučenim graničnim vrijednostima

$$
f_{n} \geq 2,861 \cdot \ln \left(\frac{K}{\xi W}\right)
$$

(ovo je u suštini jed. 4, preoblikovana tako da se izrazi vlastita frekvencija konstrukcije ovisno 0 efektivnoj težini i koeficijentu prigušenja, uzimajući u obzir maksimalno dopušteno ubrzanje konstrukcije zbog vibracija pri hodanju, veličine $0,5 \% \mathrm{~g}$ )

pri čemu su

\begin{tabular}{|l|c|c|}
\hline & Koeficijent $K$ & $\begin{array}{c}\text { Koeficijent } \\
\text { prigušenja } \xi\end{array}$ \\
\hline Poslovne i stambene zgrade, crkve & 58 & $0,02-0,05$ \\
\hline Trgovački centri & 20 & 0,02 \\
\hline
\end{tabular}


Tablica 6 - Pregled kriterija ocjene ponašanja odabranih konstrukcija

\begin{tabular}{|c|c|c|c|c|c|}
\hline \multicolumn{3}{|c|}{ Spregnuta konstrukcija } & \multicolumn{3}{c|}{ Armiranobetonska ploča } \\
\hline kriterij & proračun & $\begin{array}{c}\text { granične } \\
\text { vrijednosti }\end{array}$ & kriterij & proračun & $\begin{array}{c}\text { granične } \\
\text { vrijednosti }\end{array}$ \\
\hline$f_{n}$ & 4,80 & 4,27 & $f_{n}$ & 8,71 & 6,94 \\
$a_{p} / g$ & $0,41 \%$ & $0,50 \%$ & $a_{p} / g$ & $0,30 \%$ & $0,50 \%$ \\
\hline \multicolumn{3}{|c|}{$\rightarrow$ Zadovoljava } & \multicolumn{3}{c|}{$\rightarrow$ Zadovoljava } \\
\hline
\end{tabular}

\subsection{Ritmičko kretanje kao dinamičko opterećenje}

Zadaća je ocijeniti zadovoljavaju li odabrane međukatne konstrukcije kriterije vibracija izazvanih ritmičkim kretanjem (kao što je na primjer vježbanje uz glazbu).

U slučaju ritmičkih kretanja, osim provjere vibracijskih karakteristika konstrukcija u odnosu na minimalnu zahtijevanu vrijednost vlastite frekvencije, potrebna je i detaljnija analiza koja se sastoji u određivanju minimalne zahtijevane frekvencije za prva tri harmonijska oblika uzbudne sile. Osim jednadžbe za minimalno potrebnu frekvenciju (jed. 8): $f_{n} \geq f \sqrt{1+\frac{k}{\left(a_{p} / g\right)} \cdot \frac{\alpha_{i} W_{p}}{W_{t}}}$, potrebne su nam i empirijske vrijednosti navedene u nastavku.

Tablica 7 - Preporučene granične vrijednosti vršnog ubrzanja izazvanog ritmičkim aktivnostima [11,13]

\begin{tabular}{|l|c|}
\hline Prostori izloženi vibracijama & $\begin{array}{c}\text { Granične vrijednosti } \\
\text { ubrzanja (\%g) }\end{array}$ \\
\hline Uredi ili stambeni prostori & $0,4-0,7$ \\
Restorani & $1,5-2,5$ \\
Prostori za ritmičke aktivnosti & $4,0-7,0$ \\
\hline
\end{tabular}

Tablica 8 - Primjena kriterija iz jednadžbe 8 [13]

\begin{tabular}{|c|c|c|c|c|}
\hline $\begin{array}{c}\text { Aktivnost } \\
\text { Granično ubrzanje } \\
\text { Konstrukcija }\end{array}$ & $\begin{array}{c}\text { Frekvencija } \\
\text { sile } \\
f[\mathrm{~Hz}]\end{array}$ & $\begin{array}{c}\text { Efektivna težina } \\
\text { sudionika } \\
W_{p}[k P a]\end{array}$ & $\begin{array}{c}\text { Ukupna } \\
\text { težina } \\
W_{u}[\mathrm{kPa}]\end{array}$ & $\begin{array}{c}\text { Minimalno zahtijevana } \\
\text { vlastita frekvencija } \\
f_{n}[\mathrm{~Hz}]\end{array}$ \\
\hline $\begin{array}{l}\text { ples i objedovanje } \\
\text { aolg = 0,02 } \\
\text { Teška konstrukcija } 5 \mathrm{kPa} \\
\text { Lagana konstrukcija } 2,5 \mathrm{kPa}\end{array}$ & $\begin{array}{l}3 \\
3\end{array}$ & $\begin{array}{l}0,6 \\
0,6\end{array}$ & $\begin{array}{l}5,6 \\
3,1\end{array}$ & $\begin{array}{l}6,4 \\
8,1\end{array}$ \\
\hline $\begin{array}{l}\text { Glazbeni koncerti i sportska } \\
\text { događanja } \\
\text { aolg = 0,05 } \\
\text { Teška konstrukcija } 5 \mathrm{kPa} \\
\text { Lagana konstrukcija 2,5 kPa }\end{array}$ & $\begin{array}{l}5 \\
5\end{array}$ & $\begin{array}{l}1,5 \\
1,5\end{array}$ & $\begin{array}{l}6,5 \\
4,0\end{array}$ & $\begin{array}{l}5,9 \\
6,4\end{array}$ \\
\hline $\begin{array}{l}\text { Aerobik } \\
\text { aolg }=0,06 \\
\text { Teška konstrukcija } 5 \mathrm{kPa} \\
\text { Lagana konstrukcija 2,5 kPa }\end{array}$ & $\begin{array}{l}8,25 \\
8,25\end{array}$ & $\begin{array}{l}0,2 \\
0,2\end{array}$ & $\begin{array}{l}5,2 \\
2,7 \\
\end{array}$ & $\begin{array}{l}8,8 \\
9,2 \\
\end{array}$ \\
\hline $\begin{array}{l}\text { Vježbe koje uključuju skakanje } \\
\text { i dizanje utega } \\
\text { aolg = 0,02 } \\
\text { Teška konstrukcija } 5 \mathrm{kPa} \\
\text { Lagana konstrukcija } 2,5 \mathrm{kPa}\end{array}$ & $\begin{array}{l}8,25 \\
5,50\end{array}$ & $\begin{array}{l}0,12 \\
0,12\end{array}$ & $\begin{array}{l}5,12 \\
2,62\end{array}$ & $\begin{array}{c}9,2 \\
10,6\end{array}$ \\
\hline
\end{tabular}


Tablica 9 - Primjena kriterija iz jednadžbe 8 [13]

\begin{tabular}{|l|c|c|c|c|}
\hline \multicolumn{1}{|c|}{ Aktivnost } & $\begin{array}{c}\text { Frekvencija } \\
\text { sile } \\
f[\mathrm{~Hz}]\end{array}$ & $\begin{array}{c}\text { Efektivna težina } \\
\text { sudionika } \\
W_{p}[\mathrm{kPa}]\end{array}$ & $\begin{array}{c}\text { Dinamički } \\
\text { koeficijent } \\
\alpha_{i}\end{array}$ & $\begin{array}{c}\text { Dinamičko } \\
\text { opterećenje } \\
\alpha_{i} W_{p}[\mathrm{kPa}]\end{array}$ \\
\hline $\begin{array}{l}\text { Ples: } \\
\text { prvi oblik }\end{array}$ & $1,5-3,0$ & 0,6 & 0,5 & 0,3 \\
\hline $\begin{array}{l}\text { Glazbeni koncert i } \\
\text { sportska događanja }\end{array}$ & $1,3-3,0$ & 1,5 & 0,25 & \\
prvi oblik & $3,0-5,0$ & 1,5 & 0,05 & 0,4 \\
drugi oblik & & & & \\
\hline $\begin{array}{l}\text { Vježbe koje ukjjučuju } \\
\text { skakanje }\end{array}$ & & & & \\
prvi oblik & $2,0-2,75$ & 0,2 & 1,5 & 0,3 \\
drugi oblik & $4,0-5,5$ & 0,2 & 0,6 & 0,12 \\
treći oblik & $6,0-8,25$ & 0,2 & 0,1 & 0,02 \\
\hline
\end{tabular}

Tablica 10 - Pregled kriterija ocjene ponašanja odabranih konstrukcija

\begin{tabular}{|c|c|c|c|c|c|}
\hline \multicolumn{3}{|c|}{ Spregnuta konstrukcija } & \multicolumn{3}{|c|}{ Armiranobetonska ploča } \\
\hline kriterij & proračun & $\begin{array}{c}\text { granične } \\
\text { vrijednosti }\end{array}$ & kriterij & proračun & $\begin{array}{c}\text { granične } \\
\text { vrijednosti }\end{array}$ \\
\hline $\begin{array}{c}f_{n} \\
a_{p} / g\end{array}$ & $\begin{array}{c}4,80 \\
48,0 \%\end{array}$ & $\begin{array}{c}9,39 \\
5,0 \%\end{array}$ & $\begin{array}{c}f_{n} \\
a_{p} / g\end{array}$ & $\begin{array}{c}8,71 \\
4,2 \%\end{array}$ & $\begin{array}{c}8,76 \\
0,50 \%\end{array}$ \\
\hline \multicolumn{3}{|c|}{$\rightarrow$ Ne zadovoljava } & \multicolumn{3}{|c|}{ Zadovoljava (za treći harmonijski oblik) } \\
\hline
\end{tabular}

\section{Zaključak}

Kod dimenzioniranja međukatnih konstrukcija na dinamičko opterećenje uzrokovano djelovanjem ljudi za stanje uporabljivosti, dvije su najznačajnije osobine krutost konstrukcije i rezonancija. Kriteriji ponašanja koji se isključivo oslanjaju na ograničavanje veličine progiba zbog promjenjivog opterećenja, kao funkcije raspona konstrukcije te odnosa raspona i visine poprečnog presjeka konstrukcijskih elemenata, osobito na primjeru laganih konstrukcija za premošćivanje velikih raspona, ne daju zadovoljavajuća rješenja. Stoga se danas više pozornosti posvećuje analizi dinamičkih svojstava konstrukcija, a osobito određivanju rezonantnih pojava te vršnog ubrzanja koji su u izravnoj vezi s time kako ljudi percipiraju određene vibracije.

U normama i pravilnicima mogu se pronaći različite tablice, krivulje i preporuke o prihvatljivim graničnim vrijednostima navedenih parametara. U ovom radu dan je pregled nekolicine takvih smjernica što bi, uz opis osnovnih parametara različitih ljudskih aktivnosti te elemenata dinamičkog ponašanja međukatnih konstrukcija, trebalo skrenuti pozornost projektanata, ali i samih korisnika. Opisano istraživanje mali je doprinos analizi jednog prilično složenog međudjelovanja: ljudska aktivnost $\leftrightarrow$ međukatna konstrukcija $\leftrightarrow$ korisnik. Nastavak istraživanja trebalo bi usmjeriti povećanju prihvatljivosti naprednijih, uistinu dinamičkih analiza ovog složenog problema.

\section{Literatura}

[1] Allen, D.E., Pernica, G. 1998: Control of floor vibration, Institute for research in construction, National research council of Canada.

[2] Bachmann, H. et al. 1996: Vibration problems in structures, Practical Guidelines, Birkhauser Verlag Basel.

[3] Collette, F.S. 2004: Comfort and vibrations on floors due to walking loads, Denmark.

[4] Čaušević, M. 2005: Dinamika konstrukcija - diskretni sustavi, Školska knjiga d.d., Zagreb. 
[5] De Silva, C.W. 2000: Vibration testing, Vibration: Fundamentals and Practice, Boca Raton: CRC Press LLC.

[6] De Silva, C.W. 2000: Appendix D: Digital Fourier analysis and FFT, Vibration: Fundamentals and Practice, Boca Raton: CRC Press LLC.

[7] Ellis, B.R., Ji, T. 2002: On the loads produced by crowds jumping on floors, Structural dynamics, EURODYN 2002, Grundman \& Schueller (eds.), Swets \& Zeitlinger, Lisse.

[8] Hansen, S.O., Sorensen, J.D. 2002: Dynamic loads due to synchronized movements of people, Structural dynamics, EURODYN 2002, Grundman \& Schueller (eds.), Swets \& Zeitlinger, Lisse.

[9] HRN EN 4886:1999

[10] Ljunggren, F. 2006: Floor vibration - Dynamic properties and subjective perception, Doctoral thesis, Lulea University of technology, USA.

[11] Mendis, P., Ngo, T. 2000: Vibration and shock problems of civil engineering structures, Vibration: Fundamentals and Practice, Boca Raton: CRC Press LLC.

[12] Mihanović, A. 1995: Dinamika konstrukcija, Građevinski fakultet Sveučilišta u Splitu, Split.

[13] Murray, T.M., Allen, D.E., Ungar, E.E. 2003: Floor vibrations due to human activity, Steel design guide series 11, American Institute of Steel Construction, LA.

[14] Naeim, F. 1991: Design practice to prevent floor vibrations, Structural steel educational council, USA. 